УДК 631.173

(c) І.О. Хітров, к.т.н., Я.О. Бабич, к.т.н., В.Г. Нікітін, .т.н., О.З. Бундза, к.т.н.

Національний університет водного господарства та природокористування

\title{
КЛЮЧОВІ СТАНДАРТИ ЯКОСТІ ОБСЛУГОВУВАННЯ ПОКУПЦІВ ПРИ КУПІВЛІ ТЕХНІКИ НА ПІДПРИЄМСТВІ ДИЛЕРА
}

Стаття присвячена ключовим стандартам якості обслуговування покупців на дилерському підприємстві. Стандарти розкривають найважливіші аспекти взаємовідносин між покупцем та дилерським підприсмством. Проаналізовано виконавчі функиіі обслуговуючого персоналу та його роль в організації технічного сервісу машин. Наведено експертну оитнку ефективності роботи дилера $і$ підприємства в изілому. Намічено напрямки подальших наукових досліджень щуодо можливості їх застосування $в$ подальшій практичній діяльності.

ДИЛЕР, ДИЛЕРСЬКЕ ПНДПРИЕМСТВО, СТАНДАРТИ ДИЛЕРА, ПОКУПЕЦЬ

Постановка проблеми. У світовій практиці, незалежно від організаційних форм обслуговування техніки, відповідальність за їі роботоздатність протягом усього періоду експлуатації лежить на фірмі-виробнику. Причому цей принцип закріплено законодавчими актами, які забороняють продаж технічних засобів без організації їх технічного обслуговування через мережу незалежних дилерських підприємств. Близько 90\% компаній-виробників техніки у світі працюють саме за такими принципами. Необхідність створення дилерської мережі в Україні не викликає сумнівів.

Аналіз останніх досліджень і публікацій. Наукові джерела містять відносно невелику кількість публікацій, присвячених особливостям діяльності дилерських сервісних підприємств 3 сільськогосподарських, будівельних, дорожніх, меліоративних машин. Значний внесок у вирішенні питань, пов'язаних 3 функціонуванням дилерських підприємств внесли такі вчені як В.П. Бичков, Я.К. Білоусько, В.В. Волгін, П.І. Гайдуцький, П.А. Денисенко, В.О. Питулько, Г.М. Підлісецький, П.Т. Саблук, B.C. Шебанін та інші. Проте, незважаючи на високий науковий рівень робіт, окремі аспекти цієї багатогранної проблеми залишаються недостатньо дослідженими, зокрема 3 розробки 
стандартів якості обслуговування покупців.

Запровадження та підтримання ключових стандартів задоволення покупців при купівлі техніки дозволить здійснити логічний крок в постійному рухові до лідерства стосовно задоволення потреб покупців i допоможуть структурувати найважливішу ланку виробничого процесу - «дилер-покупець».

Метою досліджень $є$ обгрунтування організаційних засад формування стандартів якості обслуговування покупців при купівлі техніки на дилерському підприємстві для оцінки ефективності його роботи.

Результати дослідження. Формування сучасного ринку машин, технічних та виробничих послуг, особливо в умовах фінансово-економічної кризи, вимагає запровадження нових підходів у взаємовідносинах між його суб'єктами [1].

Основою розвитку дилерських підприємств $є$ всебічне задоволення покупців з наданням послуг найвищого рівня. 3 метою допомогти дилерам визначити напрямки та ступінь ефективності їх діяльності необхідно розробити стандарти задоволення потреб саме покупців (клієнтів).

Необхідно врахувати, що для того, щоб завоювати нового покупця, може знадобитися в п'ять разів більше зусиль. Більш того, задоволені покупці не тільки повертатимуться на обслуговування, ремонт та за новою технікою - вони також рекомендуватимуть дане підприємство та його дилерів своїм знайомим.

Стандарти якості обслуговування - це зусилля всього дилерського підприємства та їх майбутній успіх залежить від всіх дилерів, що запроваджують і притримуються їх. Вони забезпечують якісний фокус та напрям для персоналу дилерського підприємства (табл. 1).

Стандарти покривають найбільш важливі аспекти взаємовідносин між покупцем та дилерським підприємством. Виконання всіх стандартів $є$ запорукою цілковитої задоволеності покупців, гарантією їхньої прихильності, а отже джерелом прибутку на довгий час. Разом з тим, для покупців немає різниці між продажом та технічним сервісом, вони сприймають дилерське підприємство як єдине ціле. Це означає, що забезпечення постійно високих стандартів обслуговування покупців досягається спільними зусиллями всієї команди. 
Таблиця 1 - Стандарти якості обслуговування покупців під час придбання техніки

\begin{tabular}{|c|c|c|}
\hline Стандарт & Чому це $є$ Стандартом & $\begin{array}{c}\text { Кого це } \\
\text { стосується }\end{array}$ \\
\hline 1 & 2 & 3 \\
\hline 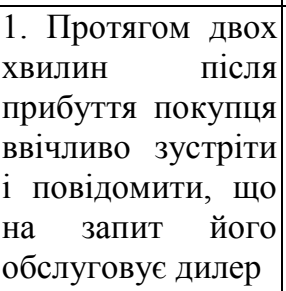 & 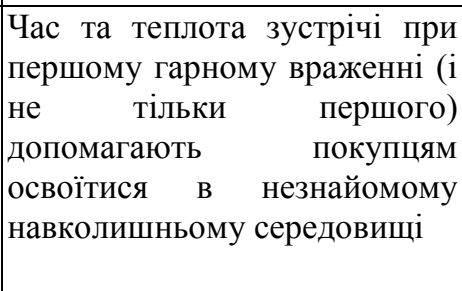 & $\mid \begin{array}{lr}\text { Це стосується } \\
\text { кожного } \\
\text { дилерському } \\
\text { підприємстві }\end{array}$ \\
\hline $\begin{array}{lr}2 . & \text { Дилеру } \\
\text { повинен } & \text { виявити } \\
\text { iнтереси } & \text { покупця } \\
\text { i } & \text { встановити } \\
\text { доброзичливі } & \\
\text { стосунки, } \\
\text { прислуховуючись } \\
\text { та визначити його } \\
\text { потреби }\end{array}$ & $\begin{array}{l}\text { Задаючи правильні запитання } \\
\text { дилер може створити } \\
\text { атмосферу довіри та порадити } \\
\text { покупцю відповідну техніку. } \\
\text { Знання та відношення дилера } \\
\text { сильно впливають на покупця }\end{array}$ & $\begin{array}{lr}\text { В першу чергу це } \\
\text { стосується дилера, } \\
\text { персоналу } \\
\text { продділу } \\
\text { будь-який } \\
\text { співробітник, що } \\
\text { розмовляє } \\
\text { покупцем, } \\
\text { повинен } \\
\text { проявляти } \\
\text { для інтерес } \\
\text { допомогт, } \\
\text { щоб } \\
\end{array}$ \\
\hline $\begin{array}{lr}3 . & \text { Персонал } \\
\text { відділу } & \text { продажу } \\
\text { за } & \text { необхідності } \\
\text { повинен } & \text { надати } \\
\text { покупцю } & \text { всі } \\
\text { необхідні } & \\
\text { пояснення. } & \text { п } \\
\text { покупця } & \text { повинно } \\
\text { залишитися } \\
\text { приємне } \\
\begin{array}{lr}\text { враження } \\
\text { покупки }\end{array}\end{array}$ & \begin{tabular}{lcc} 
Надання & всієї & \multicolumn{1}{c}{ необхідної } \\
iнформації & в чіткій та \\
дружній & манері \\
побопомагає \\
імоворати відносини і більш \\
імовно веде до покупки
\end{tabular} & $\mid \begin{array}{lr}\text { Такий } & \text { підхід } \\
\text { застосовується } & \text { на } \\
\text { кожній } & \text { стадії } \\
\text { процесу продажу і } \\
\text { включає } \\
\text { відповідальних } \\
\text { фінансування } \\
\text { зустрічний } \\
\text { продаж }\end{array}$ \\
\hline
\end{tabular}


Продовження табл. 1

\begin{tabular}{|c|c|c|}
\hline 1 & 2 & 3 \\
\hline $\begin{array}{l}4 . \\
\text { Використовуючи } \\
\text { контрольний } \\
\text { листок, дилер } \\
\text { поставить техніку } \\
\text { у бездоганному } \\
\text { стані } \\
\text { узгджений час }\end{array}$ & $\begin{array}{l}\text { Поставка - це особлива подія. } \\
\text { Все повинно бути абсолютно } \\
\text { правильно. } \\
\begin{array}{lr}\text { контрольного } \\
\text { демонструє }\end{array} \\
\text { підвищує } \\
\text { покупця. }\end{array}$ & $\begin{array}{lr}\text { Кожен } & \text { хто } \\
\text { займається } \\
\text { обробкою } \\
\text { документів } \\
\text { техніку, на } \\
\text { обслуговуванням, } \\
\text { перевіркою } \\
\text { поставкою повинен } \\
\text { забезпечити } \\
\text { підтримку п пону } \\
\text { персоналу } \\
\text { продажів }\end{array}$ \\
\hline $\begin{array}{l}5 . \\
\text { познайомить Дилер } \\
\text { покупця } \\
\text { командою відділу } \\
\text { сервісу/запчастин, } \\
\text { щоб забезпечити } \\
\text { впевненість } \\
\text { тому, шо шо } \\
\text { покупця } \\
\text { піклуються } \\
\text { протягом всього } \\
\text { періоду, коли він } \\
\text { є власником }\end{array}$ & $\begin{array}{l}\text { Робота, виконана персоналом } \\
\text { відділом продажу } \\
\text { становленню гарних відносин } \\
3 \text { покупцем, має бути } \\
\text { продовжена персоналом, який } \\
\text { займається обслуговуванням } \\
\text { після продажу. Гідне } \\
\text { знайомство - перший крок }\end{array}$ & $\begin{array}{lr}\text { Персонал } & \text { відділів } \\
\text { сервісу } & \text { та } \\
\text { запчастин } & \text { завжди } \\
\text { повинен } & \\
\text { знаходити } & \text { час, } \\
\text { щоб зустрітися } & 3 \\
\text { новими } & \\
\text { покупцями } & \\
\text { дилерського } \\
\text { підприємства та } \\
\text { розповісти про п про } \\
\text { весь діапазон } \\
\text { обслуговування } \\
\text { після продажу }\end{array}$ \\
\hline \begin{tabular}{|cr}
6. & Дилер \\
3в’яжеться & усіма \\
покупцями & через \\
$3-5 \quad$ днів & після \\
поставки &
\end{tabular} & $\begin{array}{l}\text { Важливо переконатися, що } \\
\text { покупці повністю задоволені } \\
\text { придбаною технікою }\end{array}$ & 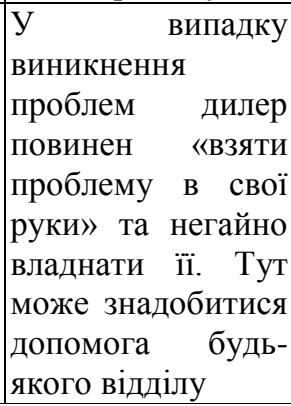 \\
\hline
\end{tabular}


При купівлі техніки дилер повинен представити покупцю такі необхідні документи: керівництво з експлуатації; інструкцію 3 монтажу, пуску, регулюванню і обкатування; паспорт (формуляр); етикетку; каталог деталей та складальних одиниць; норми витрат запасних частин; норми витрат матеріалів; відомість запасних частин і виробів; відомість експлуатаційних документів [2].

Після продажу техніки дилери надсилають інформацію про покупців, до відділу контролю за рівнем сервісу. Інформація повинна містити наступні відомості:

1. Повну назву дилерського підприємства, через який було продано техніку.

2. Ім'я та прізвище дилера 3 продажу техніки, який обслуговував цього покупця.

3. Інформацію про техніку.

4. Дату отримання техніки дилерським підприємством.

5. Дату продажу.

6. Інформація про покупця (назва організації, якій продано техніку з зазначенням повної контактної адреси).

7. Інформація про проведення відповідного технічного обслуговування або ремонту (дата, вид робіт тощо).

Базуючись на стандартах задоволення потреб покупців, можна розробити анкети для виявлення ефективності роботи відділів сервісу, запчастин та продажу техніки. Анкетування дозволить покращити роботу відділів дилерського підприємства та краще зрозуміти, в якому напрямку необхідно поліпшити технічний сервіс (рис. 1).

Для ефективності отриманих результатів анкетування бажано проводити шляхом телефонного опитування покупців не пізніше двох тижнів після того, як вони придбали техніку або проведеного обслуговування.

Дилер $з$ продажу, працівник 3 технічного сервісу може набрати максимальну кількість балів (100) у випадку, якщо покупець буде «цілком задоволений» усіма аспектами роботи, і набрати нуль балів, якщо покупець залишиться «абсолютно незадоволеним». Відповідно до цього підраховується вартість кожної відповіді покупця. Усім покупцям, які дали відповіді на поставлені запитання, надсилається лист з подякою та невеличкий сувенір. 


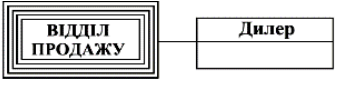

Дата розмови

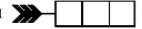

Дата обслуговування

Покупець

Посада

Назва організації

$\mathrm{C} /$ г машина, марка, рік
Контактна адреса покупця

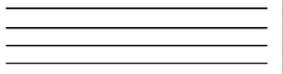

Після отримання машини, наскільки Ви задоволені якістю обслуговування в таких аспектах

1. Наскільки швидко співробітники відділу змогли приділити Вам увагу?

2. Чи був персонал ввічливий та уважний до Вac?

3. Чи отримали Ви вичерпну інформацію про

машину, яка Вас цікавила?

4. Чи отримали Ви машину у бездоганному стані?

5. Чи отримали Ви машину бажаної комплектанії?

6. Чи отримали Ви машину протягом терміну, про

який домовлялися попередньо?

7. Чи задоволені Ви послугами дилера?

8. Чи були Ви після придбання представлені

співробітникам відділів Сервісу та Запчастин?

9. Що в організації роботи дилерського

підприемства, з Вашої точки зору, потребуе

вдосконалення?
AHKETA

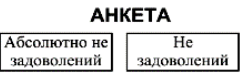

\section{васконаления}

Код дилера

Загальна оцінка роботи дилера

Рис. 1 - Анкета опитування покупців щодо ефективності роботи відділу продажу машин

Отримані дані обробляються співробітниками відділу контролю та надаються генеральним менеджерам дилерського підприємства на щомісячних нарадах. В кінці кожного календарного періоду проводиться їх систематизація та узагальнення у наведеній нижче формі:

1. Для кожного співробітника підраховується результат опитування по кожному пункту кожного питання щомісячно (рис. 2). Кількість та відсоткове співвідношення відповідей покупця (за десятибальною системою) для кожного співробітника містяться в обліковій картці відповідного відділу дилерського підприємства. Ці дані можуть допомогти визначити слабкі місця та проблемні зони роботи кожного співробітника.

2. Загальна кількість балів, набраних відділом, зводиться до спільної таблиці та підраховується їх середня кількість, набраних за поточний період, що дає можливість наочно порівняти ефективність роботи відділу за звітний період (рис. 3).

3. Загальні дані за поточний період також наводяться у таблиці якісного задоволення покупців різними аспектами їх обслуговування на дилерському підприємстві і допоможе визначити напрямки, на які необхідно звернути увагу відділу продажу (рис. 4).

4. Всі дані заносяться у спільну таблицю показників роботи співробітників, за допомогою якої можна порівняти їх показники роботи (рис. 5). 


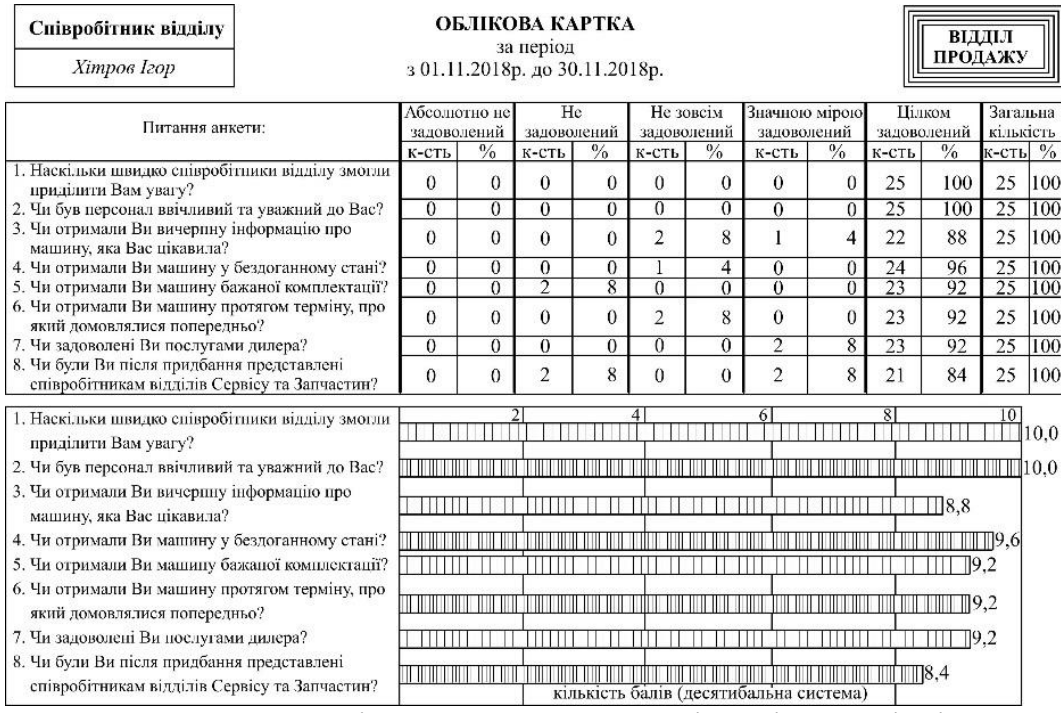

Рис. 2 - Облікова картка роботи співробітника відділу продажу машин

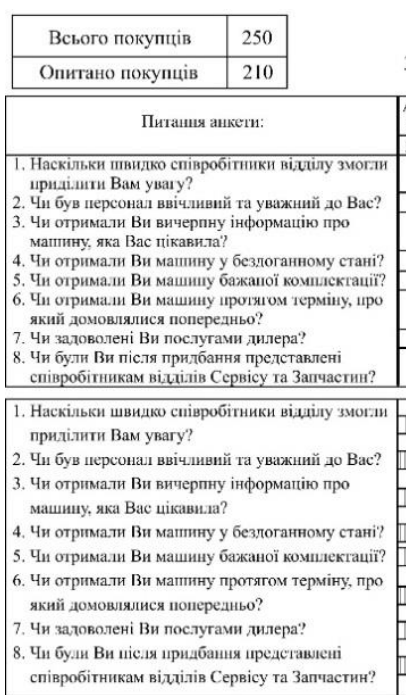

3BIT

за поточний період

301.11 .2018 p. до 30.11 .2018 p.

\begin{tabular}{|c|c|c|c|c|c|c|c|c|c|c|c|}
\hline \multicolumn{2}{|c|}{$\begin{array}{l}\text { Абсолютно не } \\
\text { заловолений }\end{array}$} & \multicolumn{2}{|c|}{$\begin{array}{c}\mathrm{He} \\
\text { заловоленшй }\end{array}$} & \multicolumn{2}{|c|}{$\begin{array}{c}\text { Не зовсім } \\
\text { задоволений }\end{array}$} & \multicolumn{2}{|c|}{$\begin{array}{c}\text { Значною мірою } \\
\text { задоволений }\end{array}$} & \multicolumn{2}{|c|}{$\begin{array}{c}\text { Цілком } \\
\text { задоволений }\end{array}$} & \multicolumn{2}{|c|}{$\begin{array}{l}\text { Загальна } \\
\text { кількість }\end{array}$} \\
\hline $\mathrm{K}-\mathrm{CTb}$ & $\%$ & $\mathrm{~K}-\mathrm{CTb}$ & $\%$ & К-CTb & $\%$ & $\mathrm{~K}-\mathrm{cTb}$ & $\%$ & $\mathrm{~K}-\mathrm{CTb}$ & $\%$ & $\mathrm{~K}-\mathrm{CTb}$ & $\%$ \\
\hline 0 & 0 & 0 & 0 & 1 & 1 & 2 & 2 & 83 & 97 & 86 & 100 \\
\hline 0 & 0 & 0 & 0 & 0 & 0 & 0 & 0 & 86 & 100 & 86 & 100 \\
\hline 0 & 0 & 1 & 1 & 8 & 9 & 1 & 1 & 76 & 88 & 86 & 100 \\
\hline 0 & 0 & 0 & 0 & 2 & 2 & 1 & 1 & 83 & 97 & 86 & 100 \\
\hline 0 & 0 & 2 & 2 & 0 & 0 & 0 & 0 & 84 & 98 & 86 & 100 \\
\hline 0 & 0 & 1 & 1 & 5 & 6 & 5 & 6 & 75 & 87 & 86 & 100 \\
\hline 0 & 0 & 0 & 0 & 0 & 0 & 5 & 6 & 81 & 94 & 86 & 100 \\
\hline 0 & 0 & 2 & 2 & 0 & 0 & 5 & 6 & 79 & 92 & 86 & 100 \\
\hline
\end{tabular}

Рис. 3 - Порівняльний звіт за поточний період роботи відділу продажу машин 


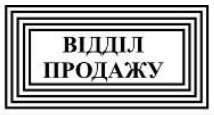

\section{ЗАУВАЖЕННЯ КЛІЕНТІВ які висловлювалися найчастіше} за період з 01.11.2018p. до 30.11.2018p.

\begin{tabular}{|l|c|r|}
\hline \multicolumn{1}{|c|}{ Зауваження покупців } & кількість & $\%$ \\
\hline Не зовсім уважне ставлення & 15 & 7,1 \\
\hline Немає інформації про подальше обслуговування & 14 & 6,7 \\
\hline Дуже дорого & 40 & 19,1 \\
\hline Тривалий термін поставки & 15 & 7,1 \\
\hline Цілком задоволених & 126 & 60 \\
\hline Кількість опитаних покупців & 210 & 100 \\
\hline
\end{tabular}

Рис. 4 - Облікова карта якісного обслуговування покупців

\begin{tabular}{|c|c|}
\hline Всього покупців & 250 \\
\hline Онитано покущців & 210 \\
\hline
\end{tabular}

ПОКАЗНИКИ РОБОТИ СПІВРОБІТНИКТВ за періол з 01.11.2018p. ло 30.11.2018p.

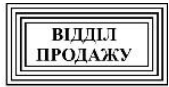

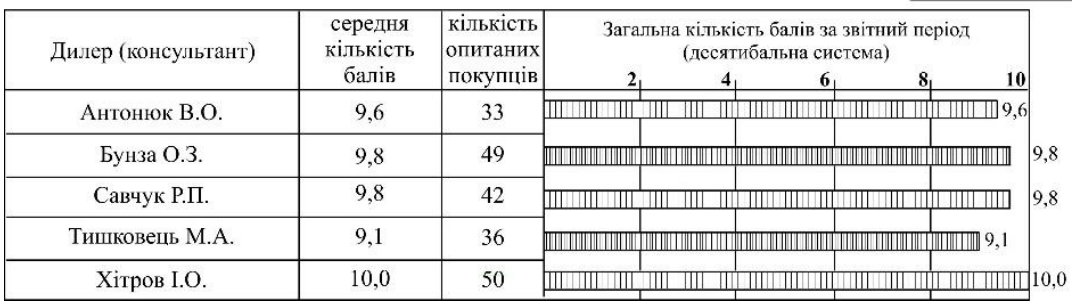

Рис. 5 - Узагальнені показники роботи співробітників відділу продажу

Висновоки. Таким чином, розроблення і запровадження стандартів задоволення потреб покупців техніки дозволять систематизувати ефективність роботи дилерського підприємства в цілому і прийняти необхідні рішення для кожного відділу. Розвиток дилерських підприємств забезпечить підвищення надійності та ефективності використання техніки шляхом надання відповідних сервісних послуг.

\section{Література}

1. Хітров І.О. Організація технічного сервісу машин дилерським підприємством / І.О. Хітров, О.З. Бундза, Я.О. Бабич / Збірник наукових статей «Сільськогосподарські машини». Вип. 40 - Луцьк, ЛНТУ, 2018. - С. 121-130. 


\section{Сільськогосподарські машини. Випуск 43}

2. Економічні аспекти державної технічної політики в агропромисловому комплексі / Білоусько Я.К., Дем'яненко М.Я., Питулько В.О., Товстопят В.Я. - Київ: IAE, 2005. - 134 с.

3. Збірник матеріалів 3 питань захисту прав покупців сільськогосподарської техніки / під заг. ред. В. Ф. Шпака. - Київ: ВГО УААІ, 2005. - 64 c. 